\title{
Analisis Kemampuan Awal dan Kepercayaan Diri terhadap Kemampuan Komunikasi Matematika
}

\author{
Farah Indrawati ${ }^{1}$, Leny Hartati ${ }^{2}$ \\ ${ }^{1}$ Program Studi Pendidikan Matematika, Universitas Indraprasta PGRI \\ ${ }^{2}$ Program Studi Pendidikan Matematika, Universitas Indraprasta PGRI \\ E-mail: farah_indrawati@yahoo.com ${ }^{1}$
}

\begin{abstract}
Abstrak
Penelitian yang dilakukan ini bertujuan untuk mengetahui pengaruh kemampuan awal dan kepercayaan diri secara bersama terhadap kemampuan komunikasi matematika, pengaruh kemampuan awal terhadap kemampuan komunikasi matematika, serta pengaruh kepercayaan diri terhadap kemampuan komunikasi matematika pada kelas non-regular mata kuliah kalkulus integral, Universitas Indraprasta PGRI (UNINDRA) Jakarta. Penelitian ini menggunakan metode survei, dengan teknik analisis regresi ganda. Sampel sejumlah 72 orang mahasiswa diambil dengan menggunakan teknik random sampling. Pengolahan data yang dilakukan menghasilkan persamaan regresi ganda $\mathrm{Y}=-2,365+0,110 \mathrm{X}_{1}+0,283 \mathrm{X}_{2}$, nilai koefisien determinasi $(\mathrm{R}$ Square $)=0,22$, $F_{\text {Hitung }}(0,787)$ lebih kecil dari $F_{\text {Tabel }}(3,126)$, serta $t_{\text {Hitung }}$ yang lebih kecil dari $t_{\text {Tabel. }}$ Kesimpulan dari penelitian ini adalah kemampuan awal dan kepercayaan diri secara bersama tidak mempunyai pengaruh yang signifikan terhadap kemampuan komunikasi matematika, kemampuan awal tidak mempunyai pengaruh yang signifikan terhadap kemampuan komunikasi matematika, dan kepercayaan diri tidak mempunyai pengaruh yang signifikan terhadap kemampuan komunikasi matematika. Penelitian ini perlu dikaji lebih lanjut karena hanya $22 \%$ nilai kemampuan komunikasi matematika yang dapat dijelaskan dengan menggunakan nilai kemampuan awal dan kepercayaan diri, sedangkan $78 \%$ harus dijelaskan oleh faktor penyebab lainnya.
\end{abstract}

Kata Kunci: kemampuan awal, kepercayaan diri, kemampuan komunikasi matematika

\section{Analysis of Initial Ability and Self Confidence on Mathematical Communication Ability}

\begin{abstract}
This research aims to determine the effect of initial ability and self confidence together on mathematical communication ability, the effect of initial ability on mathematical communication ability, and the effect of self confidence on mathematical communication ability in non-regular classes in integrated calculus courses at Universitas Indraprasta PGRI (UNINDRA) Jakarta. This study uses a survey method, with multiple regression analysis techniques. The sample of 72 students were taken using a random sampling technique. The data processing carried out results in a multiple regression equation $Y=-2.365+0.110 X_{1}+0.283 X_{2}$, the coefficient of determination ( $R$ Square $)=$ $0.22, F_{\text {Count }}(0.787)$ smaller than $F_{\text {Table }}(3.126)$, and $t_{\text {Count }}$ smaller than $t_{\text {Table }}$. The conclusion of this study is the initial ability and self confidence together do not have a significant effect on mathematical communication ability, the initial ability does not have a significant effect on mathematical communication ability, and self confidence has no significant effect on mathematical communication ability. This study needs to be studied further because only $22 \%$ of the value of mathematical communication ability can be explained by using the initial ability value and self confidence, while $78 \%$ must be explained by other causative factors.
\end{abstract}

Keywords: initial ability, self confidence, mathematical communication ability 


\section{PENDAHULUAN}

Tantangan dalam persaingan di berbagai bidang kehidupan pada jaman era globalisasi saat ini semakin hari semakin ketat. Hal tersebut menuntut pemerintah, masyarakat, dan individu mempunyai kemampuan untuk merespon cepat perubahan-perubahan serta dampak-dampak yang akan terjadi, baik positif maupun negatif. Salah-satu faktor penting yang sangat dibutuhkan dalam menghadapi era globalisasi ini adalah pendidikan. Pendidikan pada umumnya merupakan salah satu upaya yang dapat memberikan pengetahuan, wawasan, keterampilan, dan keahlian tertentu kepada individu dalam mengembangkan bakat dan kepribadian. Pendidikan yang bermutu diharapkan kedepannya dapat melahirkan generasi penerus atau sumber daya manusia yang mampu bersaing sehat dalam meraih peluang yang ada demi kemajuan bangsa dan negara. Sopamena (2018) mengatakan bahwa Indonesia harus mengikuti standar internasional agar tetap survive dalam rangka memasuki era masyarakat ekonomi ASEAN (MEA) 2015, demikian halnya pendidikan matematika yang harus berprestasi di dunia internasional.

Rahayu dan Anggun (2019) mengatakan bahwa sistem pembelajaran matematika di Indonesia perlu dibenahi dalam menghadapi era globalisasi. Hal tersebut berkaitan dengan peranan matematika yang sangat penting dalam segala jenis dimensi kehidupan, dan merupakan suatu hal yang paling urgent dalam kesuksesan komunikasi dan informasi saat ini. Pembelajaran matematika bertujuan untuk mempersiapkan generasi penerus bangsa agar dapat menghadapi berbagai perubahan yang terjadi dalam kehidupan, secara logis, rasional, cermat, kritis, kreatif dan efisien. Reformasi dalam pembelajaran matematika perlu dilakukan sebagai salah-satu upaya mengantisipasi perkembangan ilmu pengetahuan dan teknologi yang semakin maju di era globalisasi. Matematika adalah sebuah bahasa dan aktivitas sosial yang dapat mengkomunikasikan berbagai ide dengan jelas, tepat dan cermat. Komunikasi dalam pembelajaran matematika perlu menjadi fokus perhatian karena individu dapat mengorganisasi dan mengkonsolidasi berpikir matematika, serta mengeksplorasikan ide-ide matematika melalui komunikasi. Keterampilan tinggi yang melibatkan pemikiran kritis, sistematis, logis, analitis, kreatif dan berkemauan tinggi melalui pembelajaran matematika sangat dibutuhkan dalam mendukung pencapaian kecakapan atau kemahiran yang menguatkan daya matematika, sehingga individu menjadi seseorang yang handal dan dapat berkompetisi secara global. Baroody dalam Umar, W (2012) mengatakan bahwa terdapat 4 hal yang harus diperhatikan dalam mengenalkan dan menggunakan matematika sebagai bahasa komunikasi, yaitu: menggunakan pendekatan realitas, membangun definisi dan notasi formal melalui situasi informal, menghubungkan istilah matematika dengan ekspresi yang dijumpai dalam keseharian, serta membandingkan dan membedakan bahasa matematika dengan bahasa sehari-hari.

Komunikasi dalam pembelajaran matematika merupakan hal penting bagi pendidik untuk memahami kemampuan peserta didik dalam menginterpretasikan serta mengekspresikan konsep dan proses pembelajaran matematika yang dipelajari. Lanani (2013) mengatakan bahwa tanpa komunikasi dalam matematika, kita akan mempunyai sedikit keterangan, data, dan fakta tentang pemahaman peserta didik dalam melakukan proses dan aplikasi matematika. Selanjutnya Wardhana dan Lutfianto (2018) berdasarkan pengalamannya mengemukakan bahwa kurangnya pemahaman konsep dasar matematika dan ketidak-percayaan diri merupakan faktor penyebab rendahnya kemampuan komunikasi matematika peserta didik. Pendidik harus memperhatikan kemampuan komunikasi matematika peserta didik dan mencari pemecahan masalah agar peserta didik dapat berkomunikasi matematika dengan baik, baik secara lisan maupun tertulis. Andriani (2017) mengatakan bahwa objek dari matematika terdiri dari fakta, keterampilan, konsep dan prinsip yang menunjukkan matematika merupakan ilmu yang mempunyai pemahaman materi baru dengan persyaratan mempunyai penguasaan materi sebelumnya. Penguasaan materi sebelumnya tersebut dapat diketahui dengan pemberian tes kemampuan awal untuk mengetahui sejauh mana tingkat penguasaan materi sebelumnya yang dimiliki oleh peserta didik.

Hariyanto (2016) mengungkapkan bahwa kemampuan komunikasi matematika peserta didik masih rendah. Peserta didik belum mampu mengkomunikasikan ide matematika secara baik, atau dikatakan belum sepenuhnya mampu memberikan argumentasi berdasarkan prinsip dan konsep matematika. Model pembelajaran konvensional (berpusat pada pendidik), jawaban yang keliru, 
langkah perhitungan yang belum terorganisir dengan baik dan tidak konsisten, serta ketidakmampuan menyatakan suatu situasi atau masalah ke dalam bentuk simbol, diagram, atau model matematika, merupakan faktor penyebab hal tersebut. Hal ini masih banyak ditemukan dalam pembelajaran matematika, terutama pada jenjang pendidikan tinggi. Berbeda dengan apa yang telah diungkapkan oleh Tanjung (2017) bahwa kemampuan awal dan model pembelajaran tidak mempunyai pengaruh terhadap peningkatan kemampuan komunikasi matematika.

Beberapa kondisi tersebut membuat peneliti mempunyai suatu pemikiran "bagaimana menciptakan suasana pembelajaran yang nyaman dan menyenangkan, serta menciptakan kesempatan yang menantang peserta didik untuk mengubah pola pikir, dari mengingat informasi sebelumnya menjadi pembelajaran yang penuh bermakna, dengan adanya permasalahan perbedaan tingkat kemampuan awal, kepercayaan diri dan kemampuan komunikasi matematika, serta faktor-faktor yang mempengaruhinya". Adanya tuntutan peneliti untuk mengkondisikan peserta didik, menggunakan metode atau strategi yang sesuai, serta menuntaskan materi yang harus dicapai dengan batasan waktu yang telah ditentukan dalam mencapai keberhasilan pembelajaran, menggerakkan peneliti untuk memfokuskan diri melakukan penelitian yang berjudul "Analisis Kemampuan Awal dan Kepercayaan Diri terhadap Kemampuan Komunikasi Matematika". Penelitian ini dilakukan untuk mengetahui pengaruh yang berada diantara kemampuan awal, kepercayaan diri, dan kemampuan komunikasi matematika lebih lanjut.

Komunikasi merupakan kunci utama untuk membangun kehidupan yang lebih baik. Individu tidak dapat bertukar pola pikir demi kemajuan atau sesuatu yang lebih baik tanpa komunikasi. Hal tersebut senada dengan apa yang diungkapkan oleh Suhaedi (2012), bahwa "komunikasi mempunyai peranan penting, karena dengan komunikasi peserta didik dapat bertukar ide, baik dikalangan peserta didik, guru, maupun lingkungannya". Ramellan (2012) juga mengatakan bahwa "dengan komunikasi, peserta didik dapat meningkatkan kosa-kata, mengembangkan kemampuan berbicara, menuliskan ide secara sistematis, dan mempunyai kemampuan belajar yang lebih baik".

Susanto (2013) mengatakan bahwa "komunikasi matematika adalah suatu peristiwa dialog atau saling berhubungan yang terjadi di lingkungan kelas, dimana terjadi pengalihan pesan, dan pesan yang dialihkan berisi materi matematika yang dipelajari oleh peserta didik". Dewi (2014) mengatakan bahwa "komunikasi matematika adalah penyampaian ide dan pengetahuan, baik secara tertulis ataupun lisan". Individu tidak mempunyai pemahaman tentang konten matematika tanpa kemampuan komunikasi matematika.

Sumarmo (dalam Humonggio, 2013) mengatakan bahwa "komunikasi matematika meliputi kemampuan : 1) menghubungkan benda nyata, gambar, dan diagram ke dalam ide matematika, 2) menjelaskan ide, situasi, dan relasi matematika secara lisan atau tulisan dengan benda nyata, gambar, grafik, dan al-jabar, 3) menyatakan peristiwa keseharian dalam bahasa atau simbol matematika, 4) mendengarkan, berdiskusi, dan menulis tentang matematika, 5) membaca dengan pemahaman atau presentasi matematika tertulis, 6) membuat konjektur, menyusun argumen, merumuskan definisi dan generalisasi, 7) menjelaskan dan membuat pernyataan tentang matematika yang telah dipelajari”. Suhendra (2015 : 722) mengatakan bahwa "kemampuan komunikasi matematika adalah suatu kemampuan untuk mengungkapkan ide atau gagasan matematika dengan bahasa sendiri". NCTM (dalam Lutfianannisak dan Ummu Sholihah, 2018) mengatakan bahwa "komunikasi matematika menekankan pada kemampuan individu dalam : 1) mengorganisasikan dan mengkonsolidasi berpikir matematis melalui komunikasi, 2) mengkomunikasikan berpikir matematis secara koheren (tersusun secara logis) dan jelas, 3) menganalisa serta mengevaluasi berpikir matematis dan strategi yang digunakan orang lain, 4) menggunakan bahasa matematika untuk mengekspresikan ide matematika secara benar".

Terkait dengan beberapa informasi mengenai komunikasi matematika tersebut diatas, Musyrifah (2015) mengatakan bahwa peserta didik akan mempunyai kemampuan komunikasi matematika yang lebih tinggi jika pendidik menggunakan pendekatan kontekstual dalam pembelajaran. Hal ini dikarenakan pendekatan kontekstual adalah pendekatan yang melibatkan dunia nyata dalam pemahaman materi pembelajaran, sehingga melatih peserta didik untuk dapat memahami simbol, ekspresi atau gambar yang ada pada materi pembelajaran. Pendekatan ini tidak berpusat kepada pendidik yang mengakibatkan peserta didik menjadi pasif dalam pembelajaran, tetapi peserta didik 
mampu mengembangkan pemikirannya dan mengeluarkan berbagai pemikiran yang berbeda. Kemampuan bersosialisasi dan kemampuan berpikir peserta didik yang terjadi melalui interaksi dapat mengoptimalkan kemampuan komunikasi matematika peserta didik. Peserta didik dalam hal ini tidak hanya aktif mengasah kemampuan menuangkan ide melalui tulisan, tetapi juga dapat mengungkapkan ide melalui lisan.

Penelitian selanjutnya yang dilakukan oleh Salahuddin (2018) menyimpulkan bahwa terdapat pengaruh tidak langsung yang signifikan antara kepercayaan diri melalui kemampuan awal terhadap kemampuan komunikasi matematika peserta didik. Masing-masing individu mempunyai kemampuan awal, kepercayaan diri dan kemampuan komunikasi matematika yang berbeda-beda. Pendidik harus mengetahui berbagai faktor yang mempengaruhi kemampuan awal, kepercayaan diri dan kemampuan komunikasi matematika peserta didik dalam proses pembelajaran. Hal tersebut dibutuhkan supaya pendidik dapat mengembangkan kemampuan awal serta meningkatkan kepercayaan diri dan kemampuan komunikasi peserta didik, sehingga peserta didik mampu beradaptasi dan memberikan respon yang baik secara lisan dan tulisan terhadap lingkungan disekitarnya.

Kemampuan merupakan suatu hal penting dalam membangun penalaran dan dapat mempengaruhi keberhasilan atau kesuksesan individu dalam menyelesaikan permasalahan kehidupan. Wang (2012) mengatakan bahwa kemampuan adalah proses penalaran yang mengarahkan pada pernyataan umum dari suatu premis. Kemampuan (ability) secara umum didefinisikan sebagai suatu penilaian terhadap apa yang telah dilakukan individu. Kemampuan mempunyai sifat alamiah dan relatif stabil, walaupun dapat berubah sepanjang waktu dengan praktik dan pengulangan. Praktik dan pengulangan tersebut dapat meningkatkan kemampuan individu dalam memahami apa yang ingin diketahui atau dipelajari.

Glaser (Hamzah Uno, 2011:15) mengatakan bahwa salah-satu komponen yang terkait dalam perencanaaan pembelajaran adalah mendiagnosa kemampuan awal peserta didik. Pendidik harus dapat melaksanakan proses pembelajaran yang baik dan bermakna, oleh karena itu pendidik dituntut untuk mengetahui kemampuan yang miliki peserta didik sebelumnya. Hal tersebut dilakukan dalam rangka merancang metode pembelajaran disesuaikan dengan materi pembelajaran yang harus disampaikan kepada peserta didik agar dapat diterima, diserap dan diaplikasikan atau diterapkan, serta dikembangkan dengan tepat dan baik. Kemampuan awal secara umum didefinisikan sebagai kemampuan yang dimiliki individu sebelum mendapatkan suatu pengetahuan baru. Hailikari (2009) mengatakan bahwa "kemampuan awal merupakan konteks asimilasi dimana materi baru saling berkaitan”, sedangkan Chu (2010) mengatakan bahwa kemampuan awal merupakan bagian dari apresiasi.

Kemampuan awal yang merupakan prasyarat awal untuk mengetahui adanya perubahan penting dapat dilakukan pada awal pertemuan sebelum materi atau saat kajian baru akan disampaikan. Hal tersebut didasari oleh beberapa penelitian yang telah dilakukan menyimpulkan bahwa individu yang mempunyai kemampuan awal yang baik akan lebih cepat memahami materi baru yang disampaikan dalam proses pembelajaran, jika dibandingkan dengan individu yang mempunyai kemampuan awal rendah atau sama sekali tidak mempunyai kemampuan awal. Kemampuan awal individu yang berbeda-beda dipengaruhi oleh banyak faktor, tetapi sejauh ini kemampuan awal individu dapat diukur dengan memberikan tes atau pertanyaan tentang materi-materi sebelumnya yang berkaitan pada awal pertemuan. Enam tingkat kemampuan awal yang harus diketahui oleh pendidik adalah: 1) mengetahui, 2) memahami, 3) aplikasi, 4) analisis, 5) sintesis, dan 6) evaluasi. Hamzah Uno (2011:60) mengklasifikasikan kemampuan awal menjadi tiga bagian, yang diantaranya adalah kemampuan yang berkaitan dengan pengetahuan yang akan diajarkan, pengetahuan diluar pengetahuan yang akan dibicarakan, dan pengetahuan mengenai keterampilan generik.

Blakenstain, dkk (2013) mengatakan bahwa "kemampuan awal memberikan petunjuk peserta didik dalam mengingat untuk memperbaiki pengetahuan serta menyelaraskan pengetahuan yang baru dipelajari dengan pengetahuan sebelumnya". Caillies dkk (dalam Firmansyah, 2017) menyatakan bahwa tidak sedikit peserta didik dalam memahami pelajaran bergantung pada kemampuan awal yang menyediakan ingatan untuk menemukan informasi yang butuhkan dan kapan informasi tersebut dibutuhkan. Yuliana, dkk (2018) menyarankan pendidik harus memperhatikan kemampuan dasar peserta didik dalam proses pembelajaran, sehingga peserta didik dapat mengikuti proses pembelajaran 
selanjutnya. Hal tersebut perlu dilakukan untuk meminimalisir kesalahan yang terjadi dalam pemahaman konsep lanjutan, akibat ketidakpahaman peserta didik terhadap kemampuan dasar dan permasalahan yang ada.

Sejalan dengan Caillies dan Yuliana, Salahuddin (2018) menyatakan dalam penelitiannya bahwa terdapat pengaruh langsung yang signifikan antara kemampuan awal terhadap kemampuan komunikasi matematika peserta didik. Pendidik yang mengetahui kemampuan awal peserta didik diharapkan dapat melaksanakan proses pembelajaran dengan baik, dalam arti materi lanjutan dapat tersampaikan sesuai tujuan dengan metode atau strategi pembelajaran yang tepat dan waktu yang telah ditetapkan. Terkait dengan beberapa informasi tersebut maka dapat dinyatakan bahwa kemampuan awal merupakan acuan dasar yang sangat penting untuk diketahui dalam mencapai keberhasilan pengetahuan lanjutan yang bersifat progresif.

Kepercayaan diri merupakan suatu unsur penting dalam meraih kesuksesan, karena kepercayaan diri sangat dibutuhkan untuk mengembangkan aktivitas dan kreativitas sebagai upaya dalam mencapai prestasi. Kepercayaan diri dapat tumbuh dari proses interaksi sosial yang sehat, serta berlangsung secara kontinu dan berkesinambungan. Kepercayaan diri berfungsi untuk mengaktualisasikan potensi diri individu yang ada. Individu yang mempunyai kepercayaan diri tinggi akan memandang dunia sebagai hal yang dapat dikendalikan, dan memandang dirinya sebagai individu yang dapat mengendalikannya.

Molloy (2010) mengatakan bahwa kepercayaan diri adalah merasa mampu, nyaman, puas dengan diri sendiri, dan pada akhirnya tidak memerlukan persetujuan orang lain. Ghufron dan Risnawati (2010) mengatakan bahwa kepercayaan diri individu dipengaruhi oleh beberapa hal yang diantaranya adalah konsep diri, harga diri, pengalaman dan pendidikan. Fishbein dan Ajzen (dalam Hapsari, 2011) mengatakan bahwa kepercayaan diri adalah suatu keyakinan. Gufron dan Rini (2011) mengatakan bahwa kepercayaan diri adalah suatu keyakinan melakukan sesuatu sebagai karakteristik pribadi yang didalamnya terdapat kemampuan diri, optimis, objektif, tanggung jawab rasional dan realistis. Martyanti (2013) mengatakan kepercayaan diri merupakan keyakinan bahwa individu mampu menanggulangi permasalahan dalam situasi terbaik dan dapat memberikan sesuatu yang menyenangkan bagi individu lainnya. Kesimpulan dari beberapa pendapat tersebut diketahui bahwa definisi dari kepercayaan diri adalah suatu keyakinan terhadap diri sendiri untuk melakukan sesuatu sebagai karakteristik pribadi yang didasari oleh konsep diri, harga diri, pengalaman dan pendidikan, sehingga tidak hanya dapat menyelesaikan permasalahan dan menyenangkan diri sendiri tetapi juga dapat menyenangkan individu lainnya.

Ignoffo (dalam Megawati, 2010) mengatakan bahwa karakteristik individu yang mempunyai kepercayaan diri adalah sebagai berikut : 1) Mempunyai cara pandang positif, 2) Yakin dengan kemampuan yang dimiliki, 3) Melakukan sesuatu sesuai dengan apa yang dipikirkan, 4) Berpikir positif dalam kehidupan, 5) Bertindak mandiri dalam mengambil keputusan, 6) Mempunyai potensi dan kemampuan. Mardatillah (2010) mengatakan bahwa ciri individu yang mempunyai kepercayaan diri adalah sebagai berikut : 1) Mengenal dengan baik kekurangan dan kelebihannya, kemudian mengembangkan potensi yang dimilikinya, 2) Membuat standar pencapaian tujuan hidup, kemudian memberikan penghargaan jika berhasil dan bekerja lagi jika tidak tercapai, 3) Intropeksi diri, tidak menyalahkan individu lain atas kekalahan atau ketidakberhasilannya, 4) Mampu mengatasi rasa cemas, tertekan, kecewa dan ketidakmampuannya, 5) Tenang dalam menjalankan dan menghadapi segala sesuatunya, 6) Berpikir positif, 7) Maju terus tanpa menoleh atau melihat ke belakang. Beberapa karakteristik tersebut membuat kepercayaan diri ini merupakan salah-satu faktor aktivitas dalam proses meraih prestasi.

Hasil survei TIMMS (2012) dalam Martyanti (2013) menyatakan bahwa pada skala internasional hanya terdapat $14 \%$ peserta didik yang mempunyai kepercayaan diri tinggi terkait matematika. Kategori kepercayaan diri peserta didik di Indonesia sejumlah $45 \%$ masih termasuk dalam kategori rendah. Peserta didik akan mengalami perubahan dalam proses pembelajaran, terutama peserta didik yang masih dalam kategori usia remaja (18-22 tahun). Proses pembelajaran akan membentuk kepercayaan diri peserta didik dari berbagai interaksi dengan lingkungan sekitar yang diperolehnya. Peran pendidik dalam hal ini sangat dibutuhkan untuk mengetahui serta memahami kesulitan dan hambatan dalam membangun kepercayaan diri peserta didik. Pendidik yang mengetahui 
kepercayaan diri peserta didik diharapkan dapat mengelola proses pembelajaran dengan baik, sehingga peserta didik mempunyai tingkat kepercayaan diri yang tinggi dan mampu menyelesaikan permasalahan kehidupan dengan cara pandang positif dan kemampuan dirinya secara komprehensif dan terintegrasi.

Penelitian Salahuddin (2018) menyimpulkan bahwa tidak terdapat pengaruh langsung yang signifikan antara kepercayaan diri terhadap kemampuan komunikasi matematika peserta didik. Tidak dijelaskan faktor apa yang menjadi penyebab hal tersebut terjadi. Pengkajian lebih lanjut sangat dibutuhkan dalam hal ini untuk mengetahui faktor-faktor yang mempengaruhi kepercayaan diri terkait dengan kemampuan komunikasi matematika.

\section{METODE}

Penelitian ini dilaksanakan selama 6 (enam) bulan di Program Studi Pendidikan Matematika, Universitas Indraprasta PGRI, Jakarta Timur. Sampel yang berjumlah 72 orang, dan diambil dengan menggunakan teknik random sampling. Sampel dalam penelitian ini merupakan mahasiswa nonreguler yang mempelajari mata kuliah kalkulus integral pada tahun ajaran 2018/2019. Jenis penelitian ini adalah penelitian kuantitatif deskriptif, yang menggunakan metode survei dan teknik analisis uji regresi ganda. Teknik pengambilan data dilakukan dengan pemberian 5 soal tes essai terbuka untuk kemampuan awal melalui kuiz pada pertemuan awal perkuliahan, dan 4 soal tes essai terbuka yang terdiri dari a dan b untuk kemampuan komunikasi matematika pada saat ujian akhir semester, serta pemberian 30 kuesioner pernyataan kepercayaan diri pada pertemuan akhir perkuliahan.

\section{HASIL DAN PEMBAHASAN}

Tabel 1 memperlihatkan profil sampel yang digunakan dalam penelitian ini. Penelitian yang dilakukan di kelas non-regular program studi pendidikan matematika ini mempunyai persentasi sampel 54,16 \% berasal dari SMA, 41,66 \% SMK, 2,77 \% MA, dan 1,38 \% STM.

Tabel 1. Profil Sampel Penelitian

\begin{tabular}{cccccc}
\hline $\begin{array}{c}\text { RES } \\
\text { P }\end{array}$ & $\begin{array}{c}\text { ASAL } \\
\text { SEKOLAH }\end{array}$ & RESP & $\begin{array}{c}\text { ASAL } \\
\text { SEKOLAH }\end{array}$ & $\begin{array}{c}\text { RES } \\
\mathbf{P}\end{array}$ & $\begin{array}{c}\text { ASAL } \\
\text { SEKOLAH }\end{array}$ \\
\hline 1 & SMA & 25 & SMA & 49 & SMK \\
2 & SMK & 26 & SMK & 50 & SMA \\
3 & SMK & 27 & SMA & 51 & SMK \\
4 & SMK & 28 & SMA & 52 & SMK \\
5 & SMK & 29 & SMA & 53 & SMK \\
6 & SMA & 30 & SMA & 54 & SMA \\
7 & MA & 31 & SMK & 55 & SMA \\
8 & SMA & 32 & SMA & 56 & SMK \\
9 & SMA & 33 & SMA & 57 & SMA \\
10 & SMK & 34 & SMA & 58 & SMK \\
11 & SMK & 35 & SMK & 59 & SMK \\
12 & SMA & 36 & SMK & 60 & SMA \\
13 & SMK & 37 & SMA & 61 & SMK \\
14 & SMA & 38 & SMA & 62 & SMK \\
15 & SMA & 39 & SMA & 63 & SMK \\
16 & SMA & 40 & SMK & 64 & SMK \\
17 & SMK & 41 & SMA & 65 & SMA \\
18 & SMA & 42 & SMA & 66 & SMA \\
19 & SMK & 43 & STM & 67 & SMA \\
20 & SMA & 44 & MA & 68 & SMA \\
21 & SMA & 45 & SMK & 69 & SMA \\
22 & SMK & 46 & SMK & 70 & SMK \\
23 & SMA & 47 & SMA & 71 & SMA \\
24 & SMK & 48 & SMA & 72 & SMA \\
\hline
\end{tabular}


Pengolahan data penelitian yang dilakukan dengan menggunakan program SPSS 20 menghasilkan data sebagai berikut:

Tabel 2. Descriptive Statistics

\begin{tabular}{lrrrrrrrrr}
\hline & $\boldsymbol{N}$ & \multicolumn{1}{c}{ Min } & Max & Mean & Median & Mode & Std. Dev & Skewness & \multicolumn{1}{c}{ Kurtosis } \\
\hline KA & 72 &, 00 & 40,00 & 16,89 & 19 & 30 & 13,28 &, 039 & $-1,38$ \\
KD & 72 & 32,00 & 75,00 & 61,60 & 62 & 59 & 5,83 & $-1,64$ & 8,34 \\
KKM & 72 &, 00 & 60,00 & 16,90 & 15 & 0 & 15,64 &, 859 &, 07 \\
Valid N (listwise) & 72 & & & & & & & & \\
\hline
\end{tabular}

Tabel 2 memperlihatkan data deskriptif dari variabel kemampuan komunikasi matematika, kemampuan awal, dan kepercayaan diri. Nilai rata-rata kemampuan komunikasi matematika yang dihasilkan adalah 16,90 dengan simpangan baku (standard deviation) 15,64, besar modus 0 dan median 15, serta nilai minimum 0 dan nilai maksimum 60. Nilai rata-rata kemampuan awal yang dihasilkan adalah 16,89 dengan simpangan baku (standard deviation) 13,28, besar modus 30 dan median 19, serta nilai minimum 0 dan nilai maksimum 40. Nilai rata-rata kepercayaan diri yang dihasilkan adalah 61,60 dengan simpangan baku (standard deviation) 5,83, besar modus 59 dan median 62, serta nilai minimum 0 dan nilai maksimum 60. Selanjutnya Tabel 2 tersebut juga memperlihatkan nilai skewness ketiga variabel yang berada diantara -2 dan 2 . Hal itu memberitahukan bahwa data ketiga variabel dalam penelitian ini berdistribusi normal atau hampir normal. Berbeda dengan yang diperlihatkan pada Tabel 3 bahwa data variabel kemampuan komunikasi matematika, kemampuan awal, dan kepercayaan diri berdistribusi tidak normal. Hal tersebut disebabkan oleh nilai signifikansi Kolmogorov-Smirnov ketiga variabel yang lebih kecil dari 0,05.

Tabel 3. Test of Normality

\begin{tabular}{lcccccc} 
& \multicolumn{3}{c}{ Kolmogorov-Smirnov $^{a}$} & \multicolumn{3}{c}{ Shapiro-Wilk } \\
\cline { 2 - 6 } & Statistic & Df & Sig. & Statistic & df & Sig. \\
\hline KA & 185 & 72 &, 000 &, 884 & 72 &, 000 \\
KD &, 130 & 72 &, 004 &, 884 & 72 &, 000 \\
KKM &, 143 & 72 &, 001 &, 889 & 72 &, 000 \\
\hline a. Lilliefors Significance Correction & & &
\end{tabular}

a. Lilliefors Significance Correction

Nilai skewness kemampuan komunikasi matematika yang tertera pada Tabel 2 lebih besar dari 0 menyebabkan bentuk kurva positif menceng ke kanan, sedangkan nilai kurtosis yang lebih kecil dari 3 menyebabkan keruncingan kurva datar atau melandai (platikurtik), seperti yang terlihat pada Gambar 1 dibawah ini.

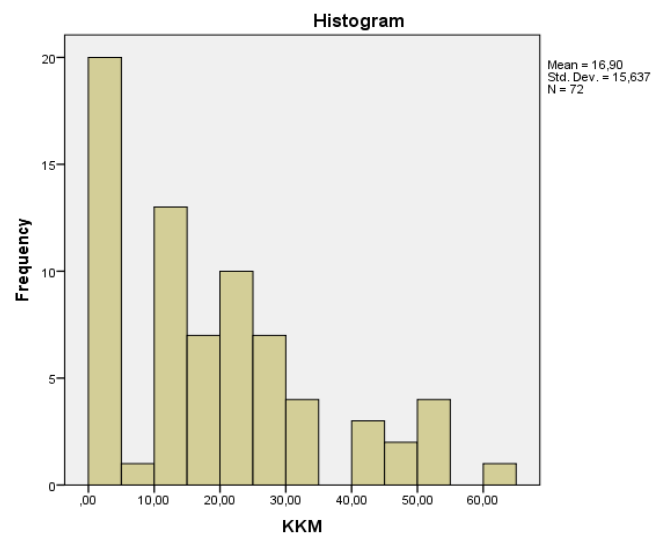

Gambar 1. Histogram Kemampuan Komunikasi Matematika

Sama seperti kemampuan komunikasi matematika, nilai skewness kemampuan awal yang tertera pada Tabel 2 lebih besar dari 0 menyebabkan bentuk kurva positif menceng ke kanan, sedangkan nilai 
kurtosis yang lebih kecil dari 3 menyebabkan keruncingan kurva datar atau melandai (platikurtik), yang terlihat pada Gambar 2 dibawah ini.

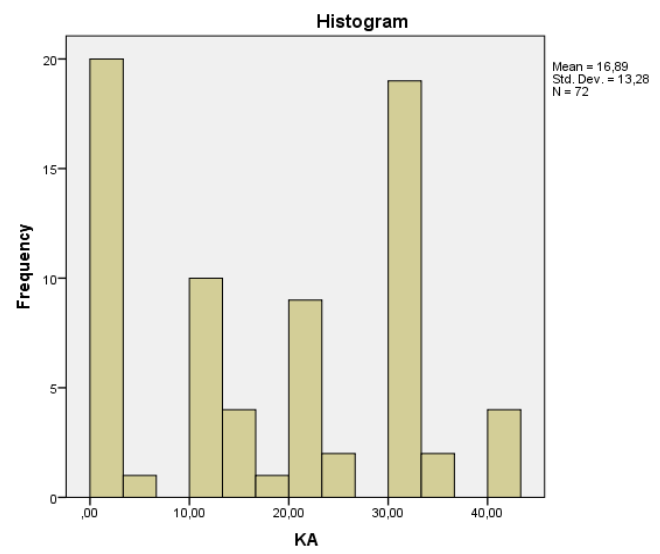

Gambar 2. Histogram Kemampuan Awal

Nilai skewness kepercayaan diri yang tertera pada Tabel 2 lebih kecil dari 0 menyebabkan bentuk kurva negatif menceng ke kiri, sedangkan nilai kurtosis yang lebih besar dari 3 menyebabkan kurva runcing (leptokurtik), seperti yang terlihat pada Gambar 3 dibawah ini.

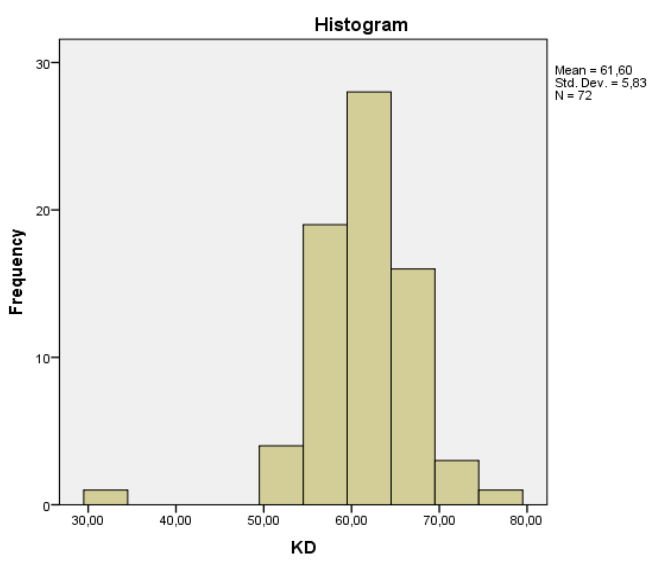

Gambar 3. Histogram Kepercayaan Diri

Tabel 4 memperlihatkan bahwa sebaran data kemampuan awal adalah heterogen karena nilai sig lebih kecil dari 0,05 , berbeda dengan sebaran data kepercayaan diri yang homogen karena mempunyai nilai sig lebih besar dari 0,05 .

Tabel 4. Test of Homogeneity of Variances

\begin{tabular}{lrccc}
\hline & Levene Statistic & df1 & df2 & Sig. \\
\hline KA & 2,373 & 7 & 58 &, 033 \\
KD &, 578 & 7 & 58 &, 771 \\
\hline
\end{tabular}

Hasil perhitungan uji linieritas regresi memperlihatkan baik kemampuan awal terhadap kemampuan komunikasi matematika, maupun kepercayaan diri terhadap kemampuan komunikasi matematika mempunyai garis regresi yang linier. Hal tersebut disebabkan oleh nilai sig pada baris Deviation from Linearity dalam Tabel 5 dan Tabel 6 dibawah adalah lebih besar dari 0,05, sehingga $\mathrm{H}_{0}$ diterima. 
Tabel 5. Linieritas Regresi Kemampuan Awal terhadap Kemampuan Komunikasi Matematika

\begin{tabular}{|c|c|c|c|c|c|c|c|}
\hline & & & $\begin{array}{l}\text { Sum of } \\
\text { Squares }\end{array}$ & df & $\begin{array}{c}\text { Mean } \\
\text { Square }\end{array}$ & $\mathbf{F}$ & Sig. \\
\hline \multirow{5}{*}{$\mathbf{K K M} * \mathbf{K A}$} & & (Combined) & 3472,07 & 10 & 347,21 & 1,525 &, 152 \\
\hline & Between Groups & Linearity & 197,17 & 1 & 197,17 & 866 & 356 \\
\hline & & Deviation from Linearity & 3274,90 & 9 & 363,88 & 1,598 &, 136 \\
\hline & Within Groups & & 13888,25 & 61 & 227,68 & & \\
\hline & Total & & 17360,32 & 71 & & & \\
\hline
\end{tabular}

Tabel 6. Linieritas Regresi Kepercayaan Diri terhadap Kemampuan Komunikasi Matematika

\begin{tabular}{|c|c|c|c|c|c|c|c|}
\hline & & & $\begin{array}{l}\text { Sum of } \\
\text { Squares }\end{array}$ & df & $\begin{array}{l}\text { Mean } \\
\text { Square }\end{array}$ & $\mathbf{F}$ & Sig. \\
\hline \multirow{5}{*}{ KKM * KD } & \multirow{3}{*}{ Between Groups } & (Combined) & 4676,36 & 20 & 233,82 & ,940 & ,543 \\
\hline & & Linearity & 238,82 & 1 & 238,82 &, 960 &, 332 \\
\hline & & Deviation from Linearity & 4437,54 & 19 & 233,55 & 939 & .542 \\
\hline & \multicolumn{2}{|l|}{ Within Groups } & 12683,96 & 51 & 248,70 & & \\
\hline & \multicolumn{2}{|l|}{ Total } & 17360,32 & 71 & & & \\
\hline
\end{tabular}

Tabel 7 memperlihatkan bahwa nilai koefisien korelasi ganda (R) antara kemampuan awal dan kepercayan diri terhadap kemampuan komunikasi matematika adalah 0,149 , koefisien determinasi (R Square) sebesar 0,22 dan nilai standar error of the estimate (SEE) yang lebih besar dari nilai simpangan baku (standard deviation), yaitu sebesar 15,64, serta nilai Durbin - Watson yang lebih besar dari 1 dan lebih kecil dari 3, yaitu sebesar 1,647.

Tabel 7. Model Summary

\begin{tabular}{cccccc}
\hline Model & $\mathbf{R}$ & $\mathbf{R}$ Square & Adjusted R Square & Std. Error of the Estimate & Durbin-Watson \\
\hline $\mathbf{1}$ &, $149^{\mathrm{a}}$ &, 022 &,- 006 & 15,681 & 1,647 \\
\hline
\end{tabular}

a. Predictors: (Constant), KD, KA

b. Dependent Variable: KKM

Nilai koefisien determinasi 0,22 memberikan arti bahwa $22 \%$ nilai kemampuan komunikasi matematika dapat dijelaskan dengan menggunakan nilai kemampuan awal dan kepercayaan diri, sedangkan $78 \%$ harus dijelaskan oleh faktor penyebab lainnya yang dianggap sebagai nilai error. Nilai Standar Error of The Estimate (SEE) yang lebih besar dari nilai standar deviasi memberitahukan bahwa nilai kemampuan awal dan kepercayaan diri secara bersama tidak layak dijadikan sebagai prediktor untuk nilai kemampuan komunikasi matematika, walaupun dalam model regresi ini tidak terjadi otokorelasi dan multikolinieritas.

$\mathrm{F}_{\text {Hitung }}$ dalam Tabel 8 pada baris regression memperlihatkan nilai sebesar 0,787 dengan tingkat signifikansi yang lebih besar dari 0,05 , yaitu sebesar 0,459. Sampel yang berjumlah 72, $\alpha=0,05$, dan derajat kebebasan $($ degree of freedom $)=2$, memperoleh $\mathrm{F}_{\text {Tabel }}=3,126$. Data tersebut memberitahukan bahwa nilai $\mathrm{F}_{\text {Hitung }}$ lebih kecil dari $\mathrm{F}_{\text {Tabel, }}$, sehingga $\mathrm{H}_{0}$ di terima dan $\mathrm{H}_{1}$ di tolak.

Tabel 8. ANOVA ${ }^{\mathrm{a}}$

\begin{tabular}{lrrccc}
\hline \multicolumn{1}{c}{ Model } & Sum of Squares & Df & Mean Square & F & Sig. \\
\hline Regression & 386,951 & 2 & 193,475 &, 787 &, $459^{\mathrm{b}}$ \\
\hline Residual & 16973,369 & 69 & 245,991 & & \\
\hline Total & 17360,319 & 71 & & & \\
\hline a. Dependent Variable: KKM & & & & \\
b. Predictors: (Constant), KD, KA & & & &
\end{tabular}

Tabel 9 memperlihatkan bahwa persamaan regresi ganda pada penelitian ini adalah $Y=-2,365+0,110 X_{1}+0,283 X_{2}$. Tabel tersebut juga memperlihatkan nilai VIF yang lebih kecil dari 5 , yaitu sebesar 1,017 , nilai $t_{H i t u n g}$ yang negatif sebesar 0,120 , nilai $t_{H i t u n g}$ kemampuan awal sebesar 0,776 , serta nilai $t_{H i t u n g}$ kepercayaan diri sebesar 0,878 . Sampel yang berjumlah 72 orang, $\alpha=0,05 / 2=0,025$ dan derajat kebebasan $($ degree of freedom $)=70$, memperoleh $\mathrm{t}_{\text {Tabel }}=1,996$. 
Nilai $\mathrm{t}_{\text {Hitung }}$ yang lebih kecil dari $\mathrm{t}_{\text {Tabel }}$ menjelaskan bahwa $\mathrm{H}_{0}$ di terima dan $\mathrm{H}_{1}$ di tolak atau dapat dikatakan bahwa baik secara masing-masing maupun bersamaan, koefisien regresi kemampuan awal dan kepercayaan diri terhadap kemampuan komunikasi matematika adalah tidak signifikan.

Tabel 9. Coefficients ${ }^{a}$

\begin{tabular}{|c|c|c|c|c|c|c|c|}
\hline \multirow[t]{2}{*}{ Model } & \multicolumn{2}{|c|}{$\begin{array}{c}\text { Unstandardized } \\
\text { Coefficients }\end{array}$} & \multirow{2}{*}{$\begin{array}{c}\begin{array}{c}\text { Standardized } \\
\text { Coefficients }\end{array} \\
\text { Beta }\end{array}$} & \multirow[t]{2}{*}{$\mathbf{T}$} & \multirow[t]{2}{*}{ Sig. } & \multicolumn{2}{|c|}{$\begin{array}{c}\text { Collinearity } \\
\text { Statistics }\end{array}$} \\
\hline & B & Std. Error & & & & Tolerance & VIF \\
\hline (Constant) & $-2,365$ & 19,753 & &,- 120 & ,905 & & \\
\hline$\underline{\mathrm{KA}}$ &, 110 &, 141 & ,093 &, 776 & ,440 & ,984 & 1,017 \\
\hline KD & ,283 & ,322 & , 105 & ,878 & ,383 & ,984 & 1,017 \\
\hline
\end{tabular}

a. Dependent Variable: KKM

Persamaan regresi yang diperoleh menunjukkan bahwa terdapat nilai Unstandardized Coefficients sebesar -2,365. Nilai tersebut merupakan besar nilai kemampuan awal dan kepercayaan diri sama dengan nol, atau dengan kata lain dapat dikatakan bahwa kemampuan komunikasi matematika akan berkurang 2,365 jika tidak ada nilai kemampuan awal dan kepercayaan diri. Nilai 0,110 memberikan arti bahwa pada setiap peningkatan 1 nilai kemampuan awal, maka nilai kemampuan pemahaman komunikasi matematika akan meningkat 0,110. Nilai 0,283 memberikan arti bahwa pada setiap peningkatan 1 nilai kepercayaan diri, maka nilai kemampuan komunikasi matematika akan meningkat 0,283 .

Hasil yang diperoleh dalam penelitian ini mengenai pengaruh kemampuan awal dan kepercayaan diri secara bersama terhadap kemampuan komunikasi matematika berbeda dengan hasil penelitian Salahuddin (2018) yang mengatakan bahwa terdapat pengaruh tidak langsung yang signifikan antara kepercayaan diri melalui kemampuan awal terhadap kemampuan komunikasi matematika. Pengkajian lebih lanjut sangat dibutuhkan dalam hal ini mengingat masih banyak terdapat faktor lain terkait dengan kemampuan awal, kepercayaan diri, dan kemampuan komunikasi matematika yang harus dijelaskan. Perolehan data kemampuan komunikasi matematika dalam penelitian ini memberitahukan bahwa masih terdapat $56,94 \%$ peserta didik yang mempunyai nilai kemampuan komunikasi matematika dibawah rata-rata. Hal tersebut terlihat juga dari jawaban yang diberikan oleh peserta didik pada saat menyelesaikan instrumen kemampuan komunikasi matematika. Jangankan menyatakan hasil, untuk membuat situasi matematika yang ada dari instrumen yang diberikan saja tidak dapat dilakukan oleh peserta didik. Peran pendidik disini sangat diperlukan dalam meningkatkan kemampuan komunikasi matematika peserta didik, terutama dalam penerapan metode pembelajaran yang tepat dan sesuai dengan kondisi peserta didik. Adanya ketepatan penerapan metode pembelajaran diharapkan dapat memotivasi peserta didik untuk selalu aktif dalam setiap proses pembelajaran, sehingga tujuan pembelajaran tercapai. Pengoptimalisasi keaktifan peserta didik dalam proses pembelajaran dapat dilakukan melalui penerapan metode pembelajaran yang interaksinya dapat meningkatkan kemampuan bersosialisasi dan kemampuan berfikir, seperti metode yang digunakan dalam model pembelajaran kooperatif atau lainnya. Selain itu, pendidik juga harus melakukan pengkajian ulang terhadap instrumen tes yang diberikan pada saat latihan soal, kuis, dan ujian setiap semesternya. Hal ini penting dilakukan untuk mengetahui apakah tujuan pembelajaran yang dicapai peserta didik, pendidik dan atau lembaga pendidikan tercapai dengan baik serta sesuai dengan apa yang telah ditetapkan oleh pemerintah.

Hasil yang diperoleh dalam penelitian ini mengenai pengaruh kemampuan awal terhadap kemampuan komunikasi matematika berbeda dengan hasil penelitian Salahuddin 
(2018) yang mengatakan bahwa terdapat pengaruh langsung yang signifikan antara kemampuan awal terhadap kemampuan komunikasi matematika. Penelitian ini belum dapat menjelaskan adanya pengaruh yang signifikan kemampuan awal terhadap kemampuan komunikasi matematika. Hal tersebut sama seperti yang diungkapkan oleh Rahmayanti, dkk (2018) bahwa tidak terdapat interaksi antara kemampuan awal terhadap kemampuan komunikasi matematika, sehingga beberapa faktor terkait kemampuan awal dan kemampuan komunikasi matematika harus dikaji lebih lanjut. Data kemampuan awal yang heterogen dalam penelitian ini memperlihatkan bahwa masih terdapat 48,61 \% peserta didik yang mempunyai nilai kemampuan awal dibawah rata-rata. Hal ini tidak hanya disebabkan oleh faktor intern peserta didik, tetapi juga disebabkan oleh faktor ekstern peserta didik. Peneliti dalam melakukan penelitian beranggapan bahwa peserta didik telah mendapatkan pembelajaran atau pernah mempelajari materi kalkulus integral pada jenjang pendidikan sekolah menengah atas atau sebelumnya. Kenyataan yang terjadi sangat berbeda pada saat pengambilan data, ternyata masih banyak terdapat peserta didik yang tidak memberikan jawaban dengan alasan belum pernah mendapatkan materi dasar kalkulus integral tersebut pada jenjang pendidikan sebelumnya, bahkan ada beberapa diantara mereka yang mengatakan telah melupakannya. Bagaimana peserta didik dapat mengevaluasi berbagai permasalahan kehidupan setelah melalui proses pembelajaran jika peserta didik tidak mengetahui juga memahami atau mampu menginterpretasikan suatu objek yang ada di sekitarnya dari berbagai segi atau sudut pandang. Adanya hal tersebut memberitahukan bahwa kesiapan peserta didik untuk menerima materi pembelajaran selanjutnya juga merupakan faktor yang sangat penting dan harus diperhatikan dalam proses pembelajaran oleh pendidik. Kesiapan dalam hal ini secara tidak langsung mempengaruhi penyelesaian instrumen kemampuan awal yang diberikan oleh peneliti. Kemampuan awal merupakan kemampuan bawaan sejak lahir, keterampilan intelektual, keterampilan kognitif, keterampilan verbal, keterampilan motorik, dan sikap pembawaan yang dapat dipelajari. Beberapa hal yang dapat dilakukan pendidik untuk mengetahui kemampuan awal peserta didik dalam meminimalisasi kesalahan pemahaman konsep pembelajaran lanjutan, diantaranya adalah melakukan pengamatan peserta didik secara perorangan, tabulasi karakteristik pribadi peserta didik, serta membuat daftar strategi karakteristik peserta didik. Pengkajian kembali keakuratan instrumen kemampuan awal yang diberikan atau disajikan oleh pendidik juga harus dilakukan untuk mengetahui apakah intrumen tersebut layak digunakan sebagai pengukur untuk mengetahui kemampuan awal peserta didik.

Hasil yang diperoleh dalam penelitian ini mengenai pengaruh kepercayaan diri terhadap kemampuan komunikasi matematika sesuai dengan hasil penelitian Salahuddin (2018). Penelitian ini juga belum dapat menjelaskan adanya pengaruh yang signifikan antara kepercayaan diri terhadap kemampuan komunikasi matematika. Hal tersebut disebabkan oleh adanya sejumlah faktor lain yang mempengaruhi kepercayaan diri peserta didik, terkait dengan kemampuan komunikasi matematika yang belum diketahui. Kepercayaan diri dapat ditingkatkan melalui keberanian yang kuat, keyakinan diri tinggi, pengetahuan luas, cara berkomunikasi dan penguasaan bahasa yang baik, serta berlatih berbicara atau berkomunikasi. Semua hal tersebut tak luput dari faktor intern dan ekstern yang terdapat pada peserta didik. Bagaimana peserta didik mengelola interaksi faktor intern dan ekstern yang terjadi sangat berpengaruh pada penyelesaian permasalahan peserta didik dalam kehidupannya. Karakteristik pribadi sangat mempengaruhi kepercayaan diri peserta didik, walaupun data variabel kepercayaan diri yang ada dalam penelitian ini adalah homogen atau seragam. Perolehan data memperlihatkan bahwa masih terdapat $47,22 \%$ peserta didik yang mempunyai nilai kepercayaan diri dibawah rata-rata. Perbedaan konsep diri, harga diri, pengalaman dan 
pendidikan peserta didik yang mendasari kepercayaan diri perlu dikaji lebih lanjut, mengingat mutu pendidikan harus terus ditingkatkan kedepannya.

\section{SIMPULAN}

Simpulan dari penelitian ini adalah kemampuan awal dan kepercayaan diri secara bersama tidak mempunyai pengaruh yang signifikan terhadap kemampuan komunikasi matematika, kemampuan awal tidak mempunyai pengaruh yang signifikan terhadap kemampuan komunikasi matematika, dan kepercayaan diri tidak mempunyai pengaruh yang signifikan terhadap kemampuan komunikasi matematika. Penelitian lebih lanjut yang memperhatikan ketepatan instrumen penelitian dan teknik analisis yang digunakan dalam pengolahan data penelitian perlu dilakukan untuk meminimalisir kesalahan, mengingat masih banyak faktor lain yang mempengaruhi kemampuan awal, kepercayaan diri, serta kemampuan komunikasi matematika yang belum dapat dijelaskan dalam penelitian ini. Peneliti menyarankan kepada pendidik untuk mengetahui kemampuan awal, kepercayaan diri, kemampuan komunikasi matematika peserta didik, dan materi pembelajaran yang harus dituntaskan dalam waktu yang telah ditentukan sebelum menyampaikan materi pembelajaran, sehingga dapat mengkondisikan peserta didik, serta memilih dan menerapkan metode mengajar yang tepat secara maksimal dalam mencapai tujuan tertentu yang telah ditetapkan. Saran untuk lembaga pendidikan, selain menyusun dan menetapkan materi pembelajaran yang disesuaikan dengan perkembangan ilmu pengetahuan pada zamannya, dalam hal ini lembaga pendidik juga harus menetapkan persyaratan tertentu pada saat penyeleksian penerimaan peserta didik baru, sehingga diperoleh keseragaman kemampuan peserta didik yang memudahkan pendidik untuk memilih dan menerapkan metode mengajar yang tepat guna mencapai tujuan lembaga.

\section{DAFTAR PUSTAKA}

Amran, dkk. 2016. Peningkatan Kemampuan Pemahaman dan Komunikasi Matematis Siswa SMAN 3 Banda Aceh melalui Penerapan Model Problem Based Learning. Jurnal Didaktik Matematika, 3(2), September 2016.

Andriani, A. 2017. Interaksi antara Model Pembelajaran dengan Kemampuan Awal Matematika terhadap Peningkatan Kemampuan Pemecahan Masalah Matematik Mahasiswa FMIPA Pendidikan Matematika. SEMNASTIKAUNIMED, Mei 2017. ISBN: 978-602-1-7980-9-6

Bidjuni, H. 2016. Hubungan Kepercayaan Diri dan Penyesuaian Diri pada Mahasiswa Baru di Program Studi Ilmu Keperawatan Fakultas Kedokteran Universitas Sam Ratulangi Manado. e-Journal Keperawatan (e-Kp), 4(2), Februari 2016.

Deswita, R., dkk. 2018. Peningkatan Kemampuan Komunikasi Matematis Siswa melalui Model Pembelajaran CORE dengan Pendekatan Scientific. Jurnal Edumatica, 1(1), Mei 2018. E-ISSN 2620-8911. p-ISSN 2620-8903.

Dwi Astuti, F. 2013. Pengaruh Kemampuan Awal dan Keaktifan Siswa terhadap Hasil Proyek Tugas Akhir pada Mata Pelajaran Pengoperasian dan Perakitan Sistem Kendali di SMK Negeri 2 Yogyakarta. Skripsi. Fakultas Teknik Universitas Negeri Yogyakarta. Yogyakarta.

Firmansyah. 2017. Peran Kemampuan Awal Matematika dan Belief Matematika terhadap Hasil Belajar. Jurnal Prima, 1(1), Juli 2017. 55-68. 
Hariyanto. 2016. Penerapan Model CORE dalam Pembelajaran Matematika untuk Meningkatkan Kemampuan Komunikasi Matematika Siswa. Jurnal Gammath, 1(2), 33 40.

Hendi Ristanto, R. 2011. Kemampuan Awal (Prior Knowledge). Sains Edutainment. http://sainsedutainment.blogspot.com/2011/04/kemampuan-awal-prior-knowledge.html

Hevriansyah, dkk. 2016. Pengaruh Kemampuan Awal Matematika terhadap Hasil Belajar Matematika. JKPM, 2(1), Desember 2016. 37-44.

Iskandar, A., Muhammad Rizal. 2017. Analisis Kualitas Soal di Perguruan Tinggi Berbasis Aplikasi TAP. Jurnal Penelitian dan Evaluasi Pendidikan, 21(2), Desember 2017. 12 23. e-ISSN: 2338-6061. p-ISSN: 1410-4725.

Jumalia. 2018. Pengaruh Kepercayaan Diri dan Kemampuan Komunikasi Matematika terhadap Hasil Belajar Matematika Siswa Kelas VIII SMP Negeri 5 Majene. Skripsi. Fakultas Matematika dan IPA, Universitas Negeri Makassar.

Lanani, K. (2013). Belajar Berkomunikasi dan Komunikasi untuk Belajar dalam Pembelajaran Matematika. Infinity Journal, 2(1):13-25.

Lestari, W. 2017. Pengaruh Kemampuan Awal Matematika dan Motivasi Belajar terhadap Hasil Belajar Matematika. Jurnal Formatif, 3(1), Juni 2017, 76-84.

Miftah, R. 2015. Pengaruh Pendekatan Model Electing Activities (MEAs) terhadap Kemampuan Komunikasi Matematis Mahasiswa Program Dual Mode System (DMS). Jurnal Edumatica, 5(1), April 2015. ISSN: 2088-2157.

Musyrifah, E. 2015. Kemampuan Komunikasi Matematika pada Pembelajaran Kalkulus melalui Pendekatan Kontekstual. Jurnal Edumatica, 5(1), April 2015. ISSN: 20882157.

Nila Ubaidah, M., Abdul Basir. 2017. Meningkatkan Kemampuan Komunikasi Matematis Siswa melalui Make a Match Berbantuan CD Pembelajaran Materi Persamaan Trigonometri Sederhana. UNISSULA, Semarang. JES-MAT, 3(1), Maret 2017.

Nurlaelah, E. 2009. Pencapaian daya dan Kreativitas Matematika Calon Guru melalui Pembelajaran berdasarkan Teori Apos. Disertasi. Tidak diterbitkan. SPS UPI Bandung.

Rahayu, LD dan Anggun BK. 2019. Peran Pendidikan Matematika di Era Globalisasi. Prosiding. Seminar Nasional Matematika dan Pendidikan Matematika (SENDIKA) Universitas Muhammadiyah Purworejo, 5(1), April 2019, 534-541. ISSN: 2459-962X.

Rahmayanti, Hasanuddin, Zulkifli Nelson. 2018. Pengaruh Penerapan Metode Pembelajaran Aktif Modelling The Way terhadap Kemampuan Komunikasi Matematis ditinjau dari Kemampuan Awal Siswa SMK Taruna Pekan Baru. Juring, 1(1), Juni 2018, 65-70. eISSN: 2621-7422. p-ISSN: 2621-7430.

Salahuddin, I. 2018. Pengaruh Kemampuan Awal, Kepercayaan Diri, Motivasi Belajar terhadap Kemampuan Komunikasi Matematika. Jurnal Penelitian Matematika dan Pendidikan Matematika PROXIMAL, 1(2), Agustus 2018. e-ISSN: 26157667. p-ISSN: 26158132.

Sarwono, J. 2012. Mengenal SPSS Statistics 20. Jakarta : Elex Media Komputindo. 
Siti, dkk. 2018. Hubungan antara Self Confidence dengan Kemampuan Berpikir Kritis Siswa dalam Pembelajaran Matematika. Jurnal Edumatica, 8(1), April 2018. e-ISSN: 25800779. p-ISSN: 2088-2157.

Sopamena, Patma. 2018. Matematika dan Era Globalisasi. FITI. IAIN Ambon.

Subanindro. 2012. Pengembangan Perangkat Pembelajaran Trigonometri Berorientasikan Kemampuan Penalaran dan Komunikasi Matematik Siswa SMA. Prosiding. Seminar Nasional Matematika dan Pendidikan Matematika UNY, Yogyakarta. ISBN : 978-97916353-8-7.

Sugiyono. 2010. Statistika untuk Penelitian. Bandung : PT Alfabeta.

Supardi. 2012. Aplikasi Statistika Dalam Penelitian. Jakarta : PT Ufuk Publishing House.

Tanjung, HS. 2017. Peningkatan Kemampuan Komunikasi dan Matematis Siswa melalui Model Pembelajaran Berbasis Masalah. Maju, 4(2), September 2017, 42-54. ISSN:2355-3782

Umar, W. 2012. Membangun Kemampuan Komunikasi Matematika dalam Pembelajaran Matematika. Infinity Journal, 1(1), Februari 2012.

Wardhana, I. R., Moch Lutfianto. Analisis Kemampuan Komunikasi Matematis Siswa ditinjau dari Kemampuan Matematika Siswa. Jurnal Pendidikan Matematika UNION, 6(2), Juli 2018 .

Wibowo. 2015. Perilaku dalam Organisasi. Jakarta : PT RajaGrafindo Persada.

Yuliana, dkk. 2018. Analisis Kesalahan Mahasiswa dalam Pemecahan Masalah pada Mata Kuliah Persamaan Differensial. Jurnal Edumatica, 8(2), Oktober 2018. e-ISSN: 25800779. p-ISSN: 2088-2157. 